\title{
Developing Skills of Systemic Thinking for Secondary Students
}

\author{
Prof. Abdul Hamid Al-Menshawi ${ }^{1}$, Salma Abu Al-Yazeed ${ }^{2}$ \\ ${ }^{1}$ Professor of Methodology and Teaching Philosophy, Dean of Faculty of Education, Tanta University \\ ${ }^{2}$ Ph.D. Researchers, Faculty of Education, Tanta University
}

\begin{abstract}
The Current Study Aims At Exploring The Effect of Some Acts And Performances To Develop Skills of Systemic Thinking For Secondary Three Students, Literary Section, By Designing A Digital Course In Philosophy. The Study Sample Included (30) Students from Om Al Mo'mneen Literary Secondary School In Tanta-Egypt. As For Implementing The Research, An Overall Digital Course In Psychology Was Designed According To Systemic Thinking In The Light of Dynamically Related Parts Besides Analyzing The Course Into Elements Divided Into Units Leading To Forming Parts Which Are Lessons. So, The Course Was Formed of Units Containing Lessons Strongly Related To The Units. Lessons Contain Educational Goals Besides Educational Videos Covering And Explaining The Lessons Which Are Presented By Activities And Tasks Students Do. Moreover, Sessions of Systemic Thinking Were Designed To Discuss Four Basic Skills: Analyzing The Main Systems Into Subsidiary Ones, Understanding Relationships Between Elements Inside The System, Removing Gaps Between Elements Inside The System And Rebuilding Systems From Their Components. A Nine - Task Test Was Designed To Measure Skills of Systemic Thinking In Psychology. Every Task Is About A Complicated Situation In Which A Student Is Required To Embody Relationships Inside The Situation In A Flow Chart. Then, A Student Is Asked To Do A Multi-Choice Question. The Aim of That Test Is To Measure Student's Ability To Think About Topics Stated In The Digital Course Content of Psychology. Results Demonstrated Progress In Systemic Thinking During Cognitive Development For The Skills of The Digital Psychology Course.
\end{abstract}

\section{Keywords: Systemic Thinking, Designing, Digital Course, Secondary School Students}

\section{Introduction}

In Her Study Confirmed That Digital Course Is A Main Element In Digital Learning System. Since It Contains Messages For Teachers, So Digital Courses Should Be Designed In The Light of Scientific Principles And Depend On Various Sources Such As Learning Theories Which Put Principles While Designing Education Subjects. To Be Effective In Achieving Goals, Educational Curriculum Should Use Instructional Technology Which Helps In Evaluating And Developing These Curricula (Khalefa, 2010). In The Beginning, Educational Designing Related Greatly To Learning Theories Which Help Specialists And Researchers To Reach To Good Ways And Principles Enabling Them To Achieve Better Learning In Different Situations. Recently, Regarding The Rapid Development In Social And Scientific System, The Systemic Thinking Arose. Besides, The Complicated Dynamics of Getting Knowledge And Summarizing Its Components Through Satellites And
Internet Maximized The Care of The Basic Components ; The Thing Which Help To Cope With The Progress In Different Sciences .Thus, Systemic Thinking Is A Good Idea To Help In Understanding The Whole Topic Instead of Handling Particulars (Efana\&Ebied 2003). (Al Men, 2002). (Al Kamel ,2003), (Efana \& r Neshwan ,2004), And(Al Khzendar (2008) Agree In Their Study That Being Clever At Systemic Thinking And Being Interactive With Environment Requirements Make The Student Able To Face Problems of Globalization And Technology Age; The Thing Which Progresses His/Her Emotional And Psychomotor Learning Aspects (Al Shahry, \& Ebeid, 2015). Systemic Thinking Is Considered A Suitable Process To Solve The Educational Problems Due To The Overall View of The Educational System Which Handles Problems In The Light of Systemic Relationships Between Its Components.

In Her Study (Ismael, 2012) Ismael Argues That Systemic Thinking Skills Are The Mental Processes 
Which Reflects The Learner's Ability To Think Systemically:-

1) Dividing the Whole Unit into Subsidiary Systems. For Example The Course Is Divided Into Sub- Units Which Form The Digital Course As A Whole.

2) Removing Gaps Inside The System. For Example, Removing Gaps between the Units And Lessons Of The Course. That Is To Say, There Must Be A Correlation Between The Part (Lesson) And The Sub - Whole (Unit) And The Main Whole (Course).

3) Understanding Relationships Inside The System. That Is To Say Each Unit Is Strongly Related To Its Lessons Which Are Also Related Besides Correlating Between Units As A Whole And The Digital Course Thoroughly.

4) Ability To Rebuild Systems From Their Components. That Is To Say The Student Is Able To Recollect The Lessons And Units To Form The Whole Digital Course. Nowadays, The Student Needs Systemic Thinking Skills And Correlated Information To Be The Basis On Which He /She Stands To Be Cognitive Manuscripts In The Long- Term Memory.

(Abo Khatwa, 2013) Carried Out A Study In Which He Designed Electronic Learning Environment Blending Between Model And Facebook Systems And Measured Its Effect on Developing Cognitive Achievement And Systemic Thinking. The Research Results Demonstrated Differences With Statistical Significance In The Pre And Post Application of The Systemic Thinking At The Favor of The Post Application And For The Experimental Group. The Results Also Confirmed The Great Effect of The Suggested Electronic Environment on Developing The Cognitive Achievement And The Systemic Thinking. Psychology Curriculum Is Naturally Effective Because It Forms Attitudes And Behavioral Values For Students And Helps Them To Overcome Problems And Carry Responsibility. Student At Secondary Stage Acquires Beliefs And Concepts Related To (His/Her) Mental Performance In Educational Situations; Consequently, A Digital Curricula A Rose To Fit The Rapid Change In Means of Communications.

\section{Methodology}

It Is Clear That Educational Organizations Do Their Best To Serve Good Chances For Students To Think, Hence The Importance of That Paper Focusing on Observing Secondary Three Students In Literary Section. While Studying Psychology Course, It Is Noted That Students Take Care of The General Concepts And Main Information And Neglect Progressing Systemic Thinking Skills. Hence, The Researcher Did That Research To Present Psychology Course In An Attractive Way To Overcome The Previous Problems And Learn How To Develop and Apply Systemic Thinking Skills. The Research Sample Included (30) Secondary Students Who
Were Chosen Randomly During The First Term of The Year (2019-2020). A Digital Psychology Course Was Designed According To The 5steps of The General Education Design Model: Analysis, Design, Development, Implementation And Evaluation (ADDIE).Moreover, The Previous Steps Were Checked By Feedback, Revision And Modification. An Accumulative Test Was Designed To Measure The Cognitive Aspect While Studying The Digital Course In Psychology Besides Designing Systemic Thinking Tests Which Are Centered on Test And Previous Studies of The Egyptian Ministry of Education. The Accumulative Test Was Formed of (30) Multi Choice Questions To Cover The Cognitive Aspect For Secondary Students .As For Systemic Thinking Test, It Covered (9) Tasks Revolving Around Skills of Systemic Thinking .Each Task Is Formed of A Complicated Situation In Which The Student Tries To Embody The Relationships In A Flow Chart. Then, A Student Is Asked To Answer Four Multi- Choice Questions After Each Task And Choose One Correct Answer. For Statistical Analysis, The Researcher Used SPSS To Measure Means And Standard Deviation By Using-Test" For The Cognitive Accumulative And Systemic Thinking Test.

\section{Results}

After Studying The Multimedia of The Digital Course Prepared By The Researcher In Psychology And Dividing The Whole Into Related Parts, Students of The Study Sample Demonstrated Good Results In The Cognitive Achievement. In The Post Application, We Remarked That There Are No Differences With Statistical Significance At Level (0.05) Between Means of The Pre And Post Application Grades In The Cognitive Achievement Test For Secondary Students At The Favor of The Post Application As Shown In The Following Table(1): -

Table (1) Statistical Significance of Differences Between Means of Performance Grades In The Cognitive Accumulative Test of The Digital Course For Secondary Three Students (Literary) In Psychology Pre/Post The Application of The Experimental Group

\begin{tabular}{|c|c|c|c|c|c|c|}
\hline Group & Means & $\begin{array}{c}\text { Standard } \\
\text { Deviation }\end{array}$ & $\begin{array}{c}\text { The } \\
\text { Number }\end{array}$ & $\begin{array}{c}\text { Degree } \\
\text { of } \\
\text { Freedom }\end{array}$ & T & Value \\
\hline Pre & 3.06 & 1.048 & 30 & 29 & 124.6 & 0,05 \\
\hline Post & 28.9 & 1.273 & & & & \\
\hline
\end{tabular}

Through Discussions And Sessions The Researcher Did Besides Designing Digital Curricula Divided Into Correlated Parts And Removing Gaps Between Elements of The Content, The Study Sample Showed Good Results In The Systemic Thinking. In The Post Application, We Remarked That There Are No Differences With Statistical Significance At Level (0.05) Between Means of The Pre And Post Application Grades In The Systemic Thinking Test For Secondary Students At The Favor of Post Application As The Following Table (2) Shows: 
Table (2) Statistical Significance of Differences Between Means of Performance Grades In The Systemic Thinking Test of The Digital Course For Secondary Three Students (Literary) In Psychology Pre/Post The Application of The Experimental Group

\section{Discussion}

Table (1) Shows Differences Between The Pre And Post Application of The Experimental Group At The Favor Of The Post One. Mean of The Pre Application Grades Was (3.067) Which Was Fewer Than The Value of The Mean of Post Application Grades (28.967). That Difference Is Statistically Significant Because Value of The Calculated "T" Was 124,670, The Value Which Is Higher Than Table Value of "T" (0.05). That Means Refusing The Current Assumption And Accepting The Other One. That Refers To Existing of Differences For The Interest of The Post Application. Thus, The Cognitive Accumulative Aspect Is Developed.

Table (2) Shows Differences Between The Pre And Post Application of The Experiment Group At The Favor Of The Post One. Mean of The Pre Application Grades Was (8.867) Which Was Fewer Than The Value of The Mean of Post Application Grades (30.3). That Difference Is Statistically Significant Because Value of The Calculated "T" Was 140.783, The Value Which Is Higher Than Table Value of "T" (0.05). That Means Refusing The Current Assumption And Accepting The Other One. That Refers To Existing of Differences For The Interest of The Post Application. Thus, The Cognitive Accumulative Aspect Is Developed.

\section{Recommendation}

1-It Is Recommended To Design Digital Courses In Psychology Curricula of The Secondary Stage To Develop Systemic Thinking.

2-It Is Recommended To Prepare Courses With Activities And Exercises.

3-Training Teachers on Teaching Methodology And Using Suitable Activities To Progress Thinking In General And Systemic Thinking Particularly.

4-Using The Results of The Current Study As Assistance In Designing Digital Courses of Psychology To Improve Students' Level And Thought.

\section{Conclusion}

- Digital Courses Are of International Importance Due To Their Effective Role In Developing Concepts And Thoughts of Teachers And Students, So Educational Organizations Must Change Their Curricula Into Digital Ones.

- Systemic Thinking Aims At Progressing Mental Skills of Students; The Thing Which Help To Correlate Between The Whole And Parts, Remove
Gaps Inside The Course And Combining Parts To Get Concepts And Information Besides Solving Problems By Using Skills of Scientific Thinking And Increasing Learning Motivation .

\begin{tabular}{|l|l|l|l|l|l|l|}
\hline Group & Means & $\begin{array}{l}\text { Standard } \\
\text { Deviation }\end{array}$ & $\begin{array}{l}\text { The } \\
\text { Number }\end{array}$ & $\begin{array}{l}\text { Degree } \\
\text { Of } \\
\text { Freedom }\end{array}$ & $\begin{array}{l}\text { T } \\
\text { Value }\end{array}$ & Sig \\
\hline Pre & 8.867 & 1.042 & 30 & 29 & 140.783 & 0.05 \\
\hline Post & 30.300 & 1.179 & & & & \\
\hline
\end{tabular}

\section{References}

[1] Khalifa, Zainab (2011): The impact of the two methods of interactive multimedia learning and electronic and participatory learning via the Internet in acquiring the skills of using optical displays for students who are suitable for the College of Education for Girls, Ain Shams University, College of Girls.

[2] William Obeid, Izzo Afaneh: (2003) thinking and school curriculum. D. Kuwait: Al-Faleh Library.

[3] Al-Menoufy, Saeed 2002)): The effectiveness of the systemic approach to teaching trigonometry and its effect on systemic thinking among high school students, the fourteenth conference, "Curricula of Education in the Light of the Concept of Performance", Volume Two, Egyptian Curricula and Teaching Methods Association.

[4] Al-Kamel, Hussein (2003): Teaching Systemic Thinking. Educational Magazine - Egypt. ((18-28-28.

[5] Ezzo Afaneh, Tayseer Nashwan (2004): The impact of metacognitive strategies in teaching mathematics on the development of systemic thinking among students of the eighth grade in Gaza, the eighth scientific conference "Dimensions missing in the curricula of science in the Arab world, the Egyptian Association for Education, Volume" 1, ( 1) July "(28-25) Al-Murjan Hotel, Ismailia, Faculty of Education, Ain Shams University, Heliopolis.

[6] Naila Al-Khazindar, Hassan Mahdi (2008): the effectiveness of a website on visual and systemic thinking in multimedia among students of the College of Education at Al-Qussa University, the eighteenth scientific conference - curricula of education and Arab human construction, (25-25 July), the method of the association Teaching, Vol. 2, Faculty of Education, Ain Shams University.

[7] Muhammad Ali al-Shehri, Muhammad Muhammad Ubaid (2015). The effectiveness of designing an e-learning environment in achieving a course of mathematics teaching methods for students of Najran University in the light of the requirements of e-learning.

[8] Ismail, Dina, (2012): The Psychology of Systematic Thinking, Cairo: Dar Al-Fikr Al-Arabi.

[9] Abu Khatwa, Al-Sayed, (2013): Designing an e-learning environment that integrates the (Model and Facebook) system and its impact on developing cognitive achievement and organizational thinking for university students. Journal of Arab Studies in Education and Psychology - Saudi Arabia. 39 (2) 192-232. 